\title{
Adaptations and repercussions in the experiences in a hybrid education university during the Sars-CoV-2 pandemic
}

Adaptações e repercussões nas vivências em escola de ensino híbrido durante a pandemia por Sars-CoV-2

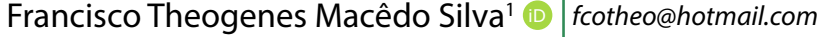 \\ Marcos Kubrusly' (D) mmkubrusly@gmail.com \\ Arnaldo Aires Peixoto Junior ${ }^{1}$ (1) arnaldoapj@gmail.com \\ Larissa Xavier Santiago da Silva Vieira' (D) larissaxsantiago@gmail.com \\ Kristopherson Lustosa Augusto' (1) $\mid$ kristopherson@hotmail.com
}

\begin{abstract}
Introduction: The pandemic caused by the SARS-CoV-2 virus has accelerated an educational revolution, with implications for health care and medical education, generating some insecurities and uncertainties. The article reports the experience of Centro Universitário Christus (Unichristus) about the changes that occurred in the practical scenarios of clinical experiences during the first semester of 2020, marked by social distancing.

Experience Report: The services at Clínica Escola de Saúde (CES) were suspended and the associated hospitals stopped receiving students, making the experience of real-life scenarios unfeasible, resulting in the beginning of a project characterized by care of patients with coronavirus infection through telemedicine. The face-to-face nursing team's participation occurred concomitantly, while students attending the eighth semester of the medical course were present at the consultation through screen sharing using the Google Meet ${ }^{\circledR}$ program. After the consultation was concluded, there was a discussion about the case and other relevant aspects, similarly to what would happen with a face-to-face experience. In parallel with the project, students also attended lectures that addressed aspects of the disease from primary to tertiary level of health care.

Discussion: Patients received care and students were taught through a flexible, innovative, accessible and safe media, following a worldwide trend, generating opportunities for professional development and innovations in medical education. The experience with telemedicine can be complemented by e-learning, allowing the development of a new hybrid teaching model.

Conclusion: The current circumstances may result in some educational loss, such as the impossibility to perform physical examinations and to interact better with the health care team and patients; however the technological resources can result in opportunities for changes, improvement and development of teaching methodologies, in line with the current generation of digital natives.
\end{abstract}

Keywords: Medical Education; Coronavirus Infections; Telemedicine.

\section{RESUMO}

Introdução: A pandemia ocasionada pelo vírus Sars-CoV-2 acelerou uma revolução educacional que repercutiu na assistência à saúde e no ensino médico, e gerou algumas inseguranças e incertezas. O artigo relata a experiência do Centro Universitário Christus (Unichristus) quanto às modificações ocorridas nos cenários práticos de vivências clínicas durante o período do primeiro semestre de 2020, marcado pelo distanciamento social.

Relato de Experiência: Os atendimentos na Clínica Escola de Saúde (CES) foram suspensos, e os hospitais conveniados passaram a não receber alunos, inviabilizando os cenários de vivência, resultando no início de um projeto caracterizado por atendimento a pacientes com infecção por coronavírus por meio da telemedicina. Havia a participação presencial de equipe de enfermagem, enquanto os alunos do oitavo semestre do curso de Medicina presenciavam a consulta por meio de compartilhamento da tela pelo programa Google Meet ${ }^{\oplus}$. Após concluída a consulta, havia uma discussão sobre o caso e outros aspectos relevantes, de maneira similar ao que ocorreria em ambiente de vivência. Em paralelo ao projeto, os estudantes também assistiam a aulas expositivas que abordavam aspectos da doença desde o nível primário até o terciário de saúde.

Discussão: De acordo com a tendência mundial, houve atendimento e ensino por um meio flexível, inovador, acessível e seguro, o gerou oportunidade de desenvolvimento profissional e inovações no ensino médico. A experiência com a telemedicina pode ser complementada por um e-learning, possibilitando o desenvolvimento de um novo modelo de ensino híbrido.

Conclusão: A circunstância atual talvez promova alguma perda educacional, como a impossibilidade de se treinar exame físico e de interagir melhor com a equipe de saúde e com os pacientes, entretanto os recursos tecnológicos podem gerar oportunidades para mudanças, aprimoramento e desenvolvimento de metodologias de ensino, em concordância com a geração atual de nativos digitais.

Palavras-chave: Educação Médica; Infecção por Coronavírus; Telemedicina.

${ }^{1}$ Centro Universitário Christus, Fortaleza, Ceará, Brazil.

Chief Editor: Daniela Chiesa

Associate Editor: Rosiane Viana Zuza Diniz

Received on 08/19/20; Accepted on 03/04/21.

Evaluated by double blind review process. 


\section{INTRODUCTION}

Since March 2020, from the moment the World Health Organization (WHO) declared COVID-19, the disease caused by the SARS-CoV-2 virus a pandemic, the world has undergone an intense revolution. Up to July 2020, there were $15,012,731$ COVID-19 cases confirmed worldwide, accounting for 619,150 deaths ${ }^{1}$. During the same period, in Brazil, more than 2 million cases were confirmed, with the state of Ceará showing one of the highest incidence rates ${ }^{2}$. This situation resulted in the publication of a decree that determined the closure of nonessential activities related to commerce, as well as public and private education institutions ${ }^{3}$.

Elective care was mostly suspended during the period, encouraging the use of remote care, even in the absence of due experience ${ }^{4}$. In Brazil, the public health system was aimed almost entirely towards the fight against coronavirus infection, with a direct impact on medical education, whether for internship students or medical residents ${ }^{5}$.

This change prevented the access to the main learning scenarios: classrooms, laboratories, simulation centers, community, hospitals, and primary care centers. Thus, the virtual environment has become the most appropriate one ${ }^{6}$. Distance learning $(\mathrm{DL})$ has become an important tool for the cognitive domain development, which allows the sharing of information, conducting research, and expanding the theoretical knowledge, in addition to reaffirming of dominant values in today's society, such as distinction and individualization ${ }^{7}$. Telemedicine can be considered in this context, expanding the scope for teaching, facilitating the acquisition of knowledge and decision making, in addition to the development of coordination and leadership skills among students ${ }^{8}$. The need for social distancing made pedagogical programs impossible, whether remote or faceto-face, making it necessary to provide a temporary system to provide instruction and educational support with a quick design, characterizing the concept of emergency remote teaching ${ }^{9}$. In the United Kingdom, practical activities and assessments in different university campuses have been blocked, with an impact on the confidence and training of students attending the last year of medical school ${ }^{10}$.

Given the entire context of insecurities and uncertainties, there is a real concern as to when and how health care will resume, as well as questions about how medical education will behave ${ }^{11}$. What obstacles are we facing and which ones will remain? What strategies can be carried out? There are several challenges and different types of solutions.

Based on this context, the article aims to report the experience of Centro Universitário Christus (Unichristus) regarding the changes that occurred in the practical scenarios of clinical experiences during the pandemic and social distancing period.

\section{EXPERIENCE REPORT}

Unichristus is a private education institution, located in the city of Fortaleza, state of Ceará, Brazil, and has an institutional Grade 5 according to the National Higher Education Assessment System (Sinaes). The medical course was implemented in 2006, with the highlight of being one of the first medical courses in Ceará to use active learning methodologies. It has a hybrid teaching plan, involving methodologies such as dialogued exhibitions, flipped classroom, simulation laboratory, problembased learning (PBL), team-based learning (TBL) and clinical experiences. The latter takes place in some affiliated hospitals belonging to the public health care network, and, mainly, at the Clínica Escola de Saúde (CES) of the university center, where there are several specialties.

The CES, one of the social arms of Unichristus, provides free care in multiple specialties, integrating care and teaching, providing the development of several living scenarios for medical students. In the center, the Specialized Care Service ( $\mathrm{SAE}$, Serviço de Atenção Especializada) program for sexually transmitted infections (STIs) and AIDS stands out, through a partnership with the Brazilian Unified Health System (SUS, Sistema Único de Saúde).

Prior to the coronavirus pandemic, all semesters preceding the ninth (first semester of medical internship) included activities with experiences defined by the semester schedule, with emphasis on the eighth semester, when several experiences took place in clinical specialties (rheumatology, cardiology, pneumology, gastroenterology, nephrology, infectology, geriatrics, psychiatry, dermatology, endocrinology and internal medicine), pediatrics and gynecology. During this period, one of the objectives is to retrieve previous knowledge, relevant to the medical internship that is imminent.

During the pandemic, due to the social distancing and the closing of educational institutions by the state government, the CES services were suspended and the affiliated hospitals stopped receiving students, making the living experience scenarios unfeasible. This conduct was even reinforced by the Regional Council of Medicine of Ceará (CREMEC), which suggested the temporary suspension of health services considered to be elective. In this context, for students attending the eighth semester and about to start the medical internship, a telemedicine project was created together with a non-governmental organization, aiming to assist patients with suspected or confirmed coronavirus infection. The telemedicine services followed CREMEC Resolution N. 56/2020, with registration in electronic medical records, guaranteeing the integrity, safety and confidentiality of the data, and the issuance of medical prescriptions and certificates if necessary, bearing the physician's digital signature. The signing of the 
patient's Free and Informed Consent Form (ICF) was mandatory for the start of care.

Teachers from different CES specialties were submitted to previous training through dialogued exhibitions on SARSCoV-2 virus infection lasting 60 minutes, followed by three hours of practice on the digital platform that was to be used. After this stage, telemedicine services were initiated, with the presence of the students in a virtual room created by the Google Meet ${ }^{\circledR}$ application. The patients, seen through another platform that contained digital medical records and video, were attended to while in the physical presence of a nursing team, responsible for checking vital signs, reading complementary exams and eventually solving a technical problem with the transmission. All professionals attending a face-to-face event followed the biosafety protocols ${ }^{12}$. The students, initially spectators, observed the remote care experience through a shared full screen and, after the consultation was concluded, there was a discussion about the case and other relevant aspects, without the patient in the room, similarly to what would happen in a real-life environment. In parallel with the project, students also watched lectures that addressed aspects of the disease at both the primary and tertiary levels of health.

Subsequently, a satisfaction survey was carried out regarding the use of telemedicine at Unichristus, involving a total of 18 students, with the following advantages being mentioned (Chart 1): reduced risk of contamination (16/18), greater savings regarding transportation and fuel (13/18), in addition to maintaining the learning process (9/18). It is worth mentioning the little experience on the part of the interviewees, since 17 students had never participated in distance learning. Some disadvantages were observed (Chart 2): impossibility to practice physical examination (18/18), less interaction with the health care team (13/18) and with the patient (15/18). The loss of non-verbal communication was seen as a disadvantage by 11 students. Depending on the quality of the internet service for good practice was mentioned as a problem by 17 students.

Infection-related rates continue to decline steadily in the state, mainly in the capital city, allowing a state government resumption plan, with partial opening of elective health services being allowed, following the biosafety criteria. The CES has resumed in-person care in the several specialties, with a smaller number of patients being scheduled, without the presence of students, according to the social distancing guidelines. After authorizing the operation of educational institutions, the intention is to return to real-life experience activities, with a restricted number of students per classroom, defined together with the institution's safety engineering department.

Chart 1. Advantages considered from the experience of practices through telemedicine by medical students ( $\mathrm{n}=18$ ).

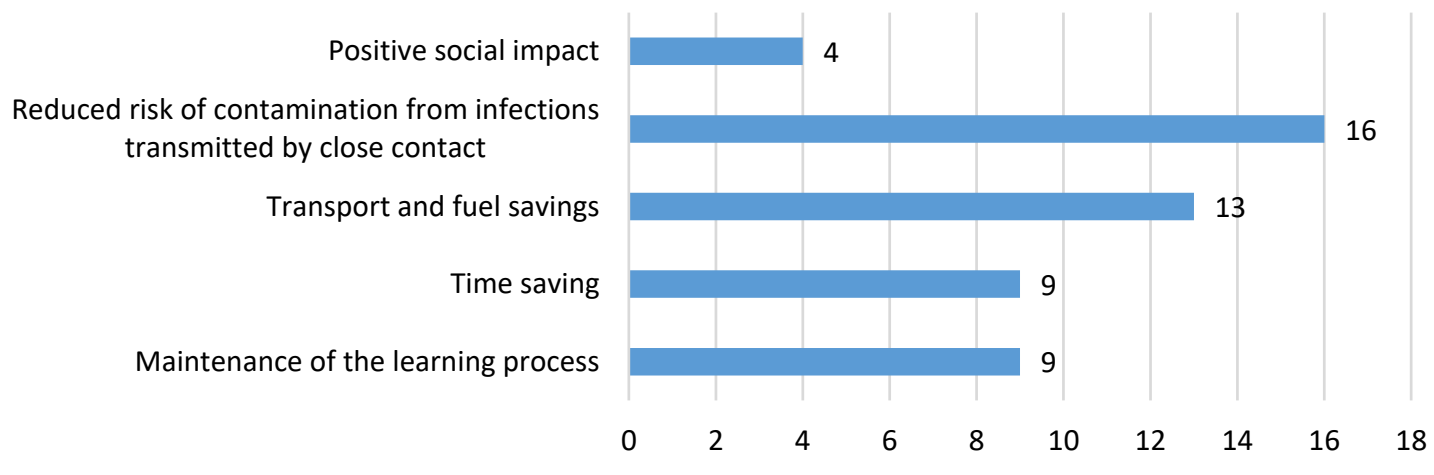

Chart 2. Disadvantages considered by students due to the lack of a face-to-face experience $(n=18)$.

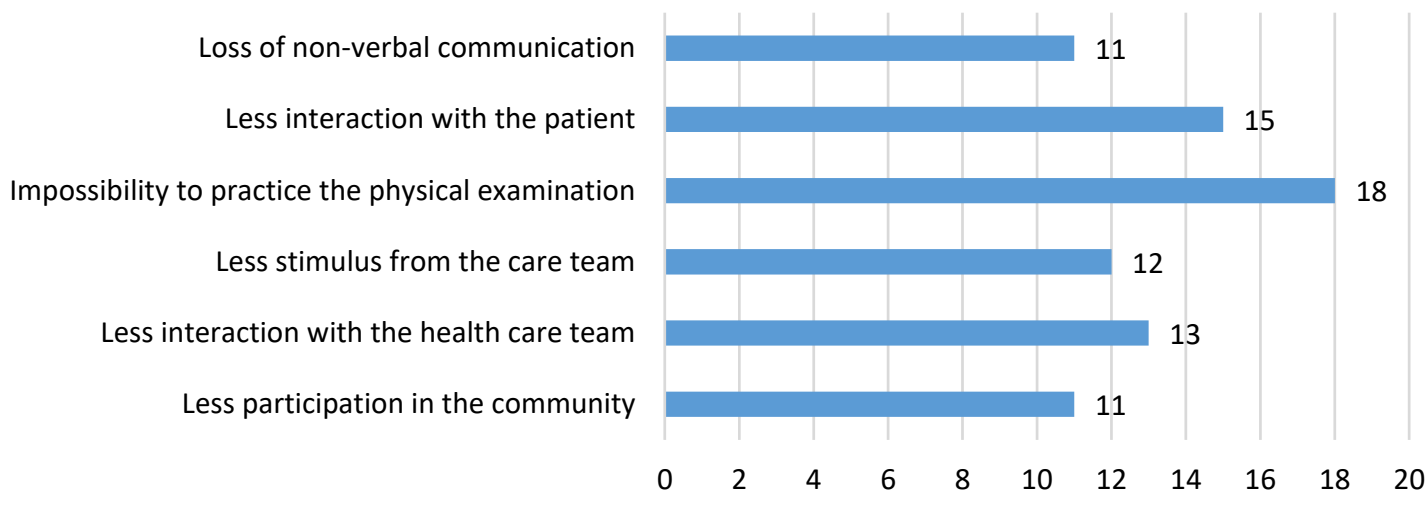




\section{DISCUSSION}

Telemedicine consists in using the Information and Communication Technologies (ICT) to perform patient's atdistance care, being useful for those located in remote areas. It is an accessible, lower-cost care system, which allows exercising equity in the health care system. In Brazil, there is great potential for the development of telemedicine, given the extensive territorial dimension and the irregular distribution of physicians in the country ${ }^{13}$.

Telemedicine was an important tool in minimizing the consequences of losing the scenario of real-life experiences during the pandemic. It was possible to offer assistance and information to the population, as well as the possibility of providing flexible, innovative, accessible and safe teaching, characteristics that are essential for remote teaching ${ }^{14}$. It is clear that the institution used a worldwide trend. In a multicenter study carried out in pediatric gastroenterology training centers in North America, it was observed that $98 \%$ of the programs did not use telemedicine before the pandemic, whereas currently, 76\% of them started using $i^{15}$. Using a tool that can improve care at a lower financial cost during this period is something to be considered ${ }^{16}$.

Other positive points can be observed. The institution aimed to follow the biosafety measures for individuals working in face-to-face activities, in addition to showing an example of social contribution at a time full of adversities. There was a clear perception about the need to change. A positive point of this pandemic period is the opportunity for professional development and innovations in medical education ${ }^{17}$. The technology, allowing at-distance discussion and sharing of information, allows the qualification on the topic in a pertinent manner. Videoconferences allow professionals from countries with greater incidence of the disease to share what is actually happening, facilitating the adoption of preventive and control measures in other locations ${ }^{18}$.

On the other hand, the absence of face-to-face experiences can generate some educational losses. Face-to-face practical activities can be beneficial, aiming to introduce the student directly into the community and make them feel as an integral part of the health care team. There is the greatest of all incentives, especially for doctors simultaneously involved in teaching and assistance activities, in face-to-face environments ${ }^{19}$.

Some technical problems regarding the quality of the internet connection and the performance of the involved platforms were observed. Data from other experiences in the literature have also reported these adversities. In another experience report involving centers on two continents (North America and Africa) during an 18-month period, it was shown that there were some interruptions in $\mathbf{3 0}$ meetings, either due to connectivity problems, audio or image delay ${ }^{20}$.
The experience report has some limitations, considering that the literature still lacks studies about the impact on students' cognitive gain during this period, and also considering this is the students' first experience with so many and varied technological tools. The impact of these teaching modalities on students' confidence and security, especially those approaching the end of medical school, needs to be better evaluated.

Despite the existing limitations, it is important to minimize, as much as possible, the exposure of students to patients infected by the SARS-CoV-2 virus, while keeping the transmission of knowledge, in addition to the fact that it is a comfortable tool for the patient ${ }^{21}$. The experience with telemedicine can be complemented by e-learning, allowing the development of a new hybrid teaching model ${ }^{22}$. The pandemic has caused a disruption in medical education, resulting in irreversible changes. Online lectures have shown to be useful; however, there is no substitute for clinical internships, which are essential for the curriculum. Virtual medical education and telehealth service, whether at home or in a hospital environment, can be proposed as a complement to practical teaching ${ }^{23}$.

\section{CONCLUSION}

It is a fact that the current circumstances may promote some educational loss, such as the impossibility of training physical examination and better interaction with the health team and the patient. However, opportunities for changes, improvement and development of teaching methodologies can be created. Remote education can be consolidated in the future, becoming a complementary means to the current teaching methods, being part of the institutional curriculum. An accessible and flexible technological tool can facilitate the students' acceptance, who belong to a generation that grew during the same period as Information and Communication Technologies (ICT), being considered digital natives ${ }^{24}$.

One can consider the current moment as before and after the pandemic, leaving the academic community, teachers and students, to reflect, extract and apply the positive experiences that occurred during the period.

\section{AUTHORS' CONTRIBUTION}

Francisco Theogenes Macêdo Silva: Writing, formatting and translation of the abstract. Marcos Kubrusly: Review of the manuscript. Arnaldo Aires Peixoto Junior: Review of the manuscript. Larissa Xavier Santiago da Silva Vieira: Writing, developing a satisfaction questionnaire on telemedicine. Kristopherson Lustosa Augusto: Review of the manuscript.

\section{CONFLICTS OF INTEREST}

The authors declare no conflicts of interest in this study. 


\section{FUNDING}

We declare that there was no funding for this research.

\section{REFERENCES}

1. World Health Organization. Coronavirus disease 2019 (Covid-19): Situation Report - 185. WHO; 2020 [access in 23 jul 2020]. Available from: https://www.who.int/docs/default-source/coronaviruse/situationreports/20200723-covid-19-sitrep-185.pdf?sfvrsn=9395b7bf_2.

2. Brasil. Painel Coronavírus. Brasília: Ministério da Saúde, Secretaria de Vigilância em Saúde; 2020 [access in 23 jul 2020]. Available from: https:// covid.saude.gov.br/.

3. Ceará. Decreto $n^{\circ} 33.519$, de 19 de março de 2020. Intensifica as medidas para o enfrentamento da infecção humana pelo novo coronavírus. Diário Oficial do Estado; 19 mar 2020. Série 3, ano XII, nº 056, p. 1-2.

4. Helou S, El Helou E, Abou-Khalil V, Wakim J, El Helou J, Daher A, et al. The effect of the Covid-19 pandemic on physicians' use and perception of telehealth: the case of Lebanon. Int J Environ Res Public Health. 2020; 17(13): 4866. doi: 10.3390/ijerph17134866..

5. Carvalho VO, Conceição LSR, Gois Jr MB. Covid-19 pandemic: beyond medical education in Brazil. J Card Surg. 2020 June 12;35(6):1170-1.

6. Valdez-García JE, Eraña-Rojas IE, Díaz Elizondo JA, Cordero-Díaz MA, Torres-Quintanilla A, Esperón-Hernández Rl, et al. The role of the medicine student in Covid-19 pandemic. A shared responsibility. Cir Cir. 2020;88(4):399-401.

7. Machado LDS, Tamboril ACR, Machado MFAS, Maia ER, Lopes MSV. Representações de profissionais residentes acerca das estratégias pedagógicas utilizadas no processo formativo da residência multiprofissional. Rev Esc Enferm USP [Internet]. 2018 [cited 2021 Mar 16] ; 52: e03386. Available from: http://www.scielo.br/scielo.php?script=sci_ arttext\&pid=S0080-62342018000100465\&Ing=en. Epub Nov 29, 2018. https://doi.org/10.1590/s1980-220×2017024803386.

8. Jumreornvong $\mathrm{O}$, Yang E, Race J, Appel J. Telemedicine and medical education in the age of Covid-19. Acad Med. 2020;95(12):1838-43.

9. Hodges C, Moore S, Lockee B, Trust T, Bond A. The difference between emergency remote teaching and online learning. Educause Review. 2020; [acesso em 16 mar 2021]. Disponível em: https://er.educause.edu/ articles/2020/3/the-difference-between-emergency-remote-teachingand-online-learning.

10. Choi B, Jegatheeswaran L, Minocha A, Alhilani M, Nakhoul M, Mutengesa E. The impact of the Covid-19 pandemic on final year medical students in the United Kingdom: a national survey. BMC Med Educ. 2020;20(1):206-16.
11. Bloom DA, Reid JR, Cassady Cl. Education in the time of Covid-19. Pediatr Radiol. 2020;50:1055-8.

12. Ceará. Plano estadual de contingência para resposta às emergências em saúde pública: novo coronavírus (2019-nCoV). Fortaleza: Secretaria da Saúde; 2020.

13. Maldonado JMSV, Marques $A B$, Cruz A. Telemedicina: desafios à sua difusão no Brasil. Cad Saude Publica. 2016:32:e00155615.

14. Koumpouras $F$, Helfgott $S$. Stand together and deliver: challenges and opportunities for rheumatology education during the Covid-19 pandemic Arthritis Rheumatol. 2020;72(7):1064-6.

15. Mallon D, Pohl JF, Phatak UP, Fernandes M, Rosen JM, Lusman SS, et al Impact of Covid-19 on pediatric gastroenterology fellow training in North America. J Pediatr Gastroenterol Nutr. 2020;71(1):6-11.

16. Shafiee HL, Caffery LJ, Freeman CR, Peeters G, Peel NM. A scoping review of the use and impact of telehealth medication reviews. Res Social Adm Pharm. 2020;16(8):1140-53.

17. McMasterD, Veremu M, SantucciC.Covid-19:opportunities for professional development and disruptive innovation. Clin Teach. 2020;17(3):238-40.

18. Gonzales-Zamora JA, Alave J, De Lima-Corvino DF, Fernandez A Videoconferences of infectious diseases: an educational tool that transcends borders. A useful tool also for the current Covid-19 pandemic. Infez Med. 2020;28(2):135-8.

19. Caldeira ES, Leite MTS, Rodrigues-Neto JF. Estudantes de Medicina nos serviços de atenção primária: percepção dos profissionais. Rev Bras Educ Med. 2011;35(4):477-85.

20. Boatin A, Ngonzi J, Bradford L, Wylie B, Goodman A. Teaching by teleconference: a model for distance medical education across two continents. Open J Obstet Gynecol. 2015;5:754-61.

21. Oldenburg R, Marsch A. Optimizing teledermatology visits for dermatology resident education during the Covid-19 pandemic. J Am Acad Dermatol. 2020;82(6):e229.

22. Theoret $C$, Ming $X$. Our education, our concerns: the impact on medical student education of Covid-19. Med Educ. 2020;54(7):591-2.

23. Kim JW, Myung SJ, Yoon HB, Moon SH, Ryu H, Yim JJ. How medical education survives and evolves during Covid-19: our experience and future direction. PLoS One. 2020;15(12):e0243958.

24. Prensky M. Nativos digitais, imigrantes digitais. On the Horizon. 2001;9(5):1-6. 